\title{
成人斜視の手術成績
}

\author{
小花佐代子・福井 優子・中岸 裕子 \\ 塚本 和子・湖崎淳・湖崎克
}

湖崎眼科

\section{Results of adalt-strabisumus surgery}

Sayoko Obana, Yuko Fukui, Hiromi Makino, Yuko Nakagishi

Kazuko Tsukamoto, Jun Kozaki, Masaru Kozaki

Kozaki eye clinic

要 約

成人の斜視は経過が長くて、その発症時期, 病態など不明な点が多く、また, 感覚異常も当然予 想され、手術は敬遠されがちである。また患者の主訴も整容目的、複視、眼精疲労などであり、手 術目的もそれらをいかに解決するかである。今回我々は、当院で初回手術を行った成人の水平斜視 48 名の結果を報告する。内訳は外斜視 33 名と内斜視 15 名であった。平均観察期間は12ヶ月であった。 治癒の評価は、1）矯正眼位が少なくとも第一眼位において患者の期待と一致する、2）眼精疲労 が軽減または消失する、3）複視が残存しても少なくとも第一眼位、さらに最も日常的に眼を用い る範囲において気にならない、とした。結果は外斜視では33名中 30 名 $(90.1 \%)$ で良好であった。こ のうち 3 名は計画的追加手術を行った。不良例は 3 名で追加手術を必要とした。内斜視では 15 名中 14名（93.3\%）で結果良好であった。不良例は 1 名で近見時、過矯正であった。成人になってから でも斜視を治したい患者は多く、術前に網膜対応検查を含め感覚的にも十分な検查をしていれば、 手術結果は良いと思われた。

別冊請求先（テ530-0001）大阪市北区梅田 3 丁目 1 - 1 アクティ大阪17階 湖崎眼科アクティ大阪分院 小 花 佐代子 Tel. 06-6345-2174 Fax. 06-6345-2168

Key words：成人斜視，斜視手術，外斜視，内斜視，複視，adult strabismus， strabismus surgery， exotropia, esotropia, double vision 


\begin{abstract}
Adult strabismus surgery is generally avoided because the condition involves different sensory problems and past histories than those of infant strabismus. Also, adults undergo surgery for reasons that are different than those of infants, for example, for cosmetic purposes, double vision and asthenopia. The most important purpose of surgery is to reduce complaints of vision problems.

We repost the results of strabismus surgery in 48 adult patients with horizontal strabismus, of which there are two types: exotropia and esotropia. There were 33 cases of exotropia and 15 cases of esotropia. The mean observation period was 12 months. We classified exotropia into two basic types: divergence excess type and convergence insufficiency type. We also classified esotropia into two basic types: divergence insufficiency type and convergence excess type. The selection of muscles and the ratio of resection-recession were determined according to these types. The most important point is to avoid double vision after surgery.

We evaluated the position of the eyes and the reduction of asthenopia and double vision after surgery. We observed that the primary eye position agreed with the patient's expectation. The reduction in asthenopia and the reduction in double vision, at least in the primary position in patients who had double vision before surgery, were concluded as being good results.

Thirty cases (90.1\%) of exotropia met with good results after surgery. Additional surgeries were planned and performed in three cases. There were three insufficient cases that required additional surgeries that were unplanned. Fourteen cases (93.3\%) of esotropia met with good results. Exotropia in nearsightedness occurred in one case.

There are many adult patients with strabismus who want to be operated on. According to our results, it is thought that strabismus surgery for such patients need not be avoided.
\end{abstract}

\section{I．緒言}

成人の斜視は小児の斜視とは異なり、経過は 長く，発症や病態も不明であり、また感覚異常 であることも多く、手術は敬遠されることが多 い。また患者の主訴も、整容、複視、眼精疲労 などで、将来的に正常両眼視機能の構築を期待 する小児とは異なる。そして手術目的もそれら の訴えをいかに解決するかである。今回我々は、 当院での成人斜視手術の成績をまとめたので報 告する。

\section{II. 対 象}

対象は平成 7 年 6 月から平成 12 年 2 月の間に 当院にて斜視手術を施行した20歳以上の斜視114 名のうち、この期間が初回手術であり、3 以上経過観察できた水平斜視48名である。その 斜視の種別、手術時年齢および斜視種別ごとの 主訴（手術を受けたい目的）は表 1 のごとくで
表 1 . 術前の内訳と主訴（手術目的）

\begin{tabular}{|c|c|c|c|}
\hline 愃常性外銤䘽 & $(n=16)$ & 43. 1 龋 & 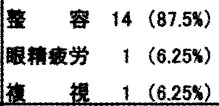 \\
\hline 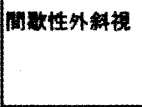 & $(n=6)$ & 35. 8 数 & 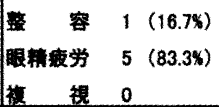 \\
\hline 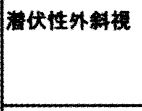 & $(n=11)$ & 39. 9 盛 & 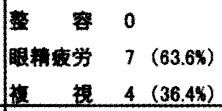 \\
\hline 臬营性内䋛視 & $(n=11)$ & 48. 3凖 & 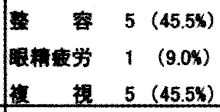 \\
\hline 问蠤性内紏視 & $(n=2)$ & 39.5 部 & 被 視 $2(100.0 \%)$ \\
\hline 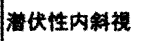 & $(n=2)$ & $57.0=$ & 被 $2(100.0 \%)$ \\
\hline
\end{tabular}

ある。上下斜視や明らかに麻疩性斜視と思われ る症例は除外した。観察期間は 3 か月から 4 年 で、平均観察期間は12.3ヶ月であった。内訳は、 
外斜視が33名（恒常性16，間歇性 6 ，潜伏性11） で手術時年齢は 22 歳から 71 歳で平均年齢は $40.4 \pm 13.8$ 歳であった。内斜視は15名（恒常性 11 , 間歇性 2 ，潜伏性 2）で、手術時年齢は23 歳から 67 歳で平均年齢は $43.5 \pm 13.8$ 歳であった。

手術目的は外斜視では整容が15名 $(45.4 \%) 、$ 眼精疲労が13名 $(39.4 \%) 、$ 複視が 5 名 $(15.2 \%)$ であった。内斜視では整容が 5 名 $(33.3 \%) 、$ 眼 精疲労が 1 名 $(6.7 \%)$ 、複視が 9 名 $(60.0 \%)$ で あった。なお、興味があるのは、恒常性外・内 斜視では整容目的が多く、潜伏性外斜視では眼 精疲労が多く、また内斜視では複視の手術目的 が多いことである。

\section{III. 方 法}

手術方針はあくまで主訴の解消にあるとはい いながら、術後の複視は絶対に避けることを重 点とした。手術適応の検査は、1）両眼の屈折、 視力検查、2）遠近の眼位検査、3）遠近の立 体視検査、4）眼位矯正後に複視が出現するか 否かの検査を行った。なお、手術目的別の遠近 の立体視検査成績は表 2 のごとくで、外斜視の 整容目的には遠近ことに遠方の立体視の存在が 認められなく、眼精疲労には立体視がほぼ存在 し、内・外斜視ともに複視の症例には立体視の

\section{表 2．術前の遠近立体視}

遠見立体視（F）は遠見ポラテスト $2 / 4$ 以上を 良好とした

近見立体視（N）はチトマスステレオテスト 6/9以上を良好とした

\begin{tabular}{|c|c|c|c|c|}
\hline & 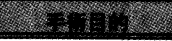 & 2 & 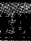 & 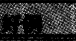 \\
\hline \multirow[t]{6}{*}{ 外紏視 $(n=33)$} & \multirow[t]{2}{*}{ 整 容 $(n=15)$} & $\mathrm{F}$ & 0 & \\
\hline & & $N$ & 4 & $(26.7 \%)$ \\
\hline & \multirow[t]{2}{*}{ 眼精度労 $(n=13)$} & $\mathrm{F}$ & 7 & $(53.8 \%)$ \\
\hline & & $N$ & 11 & $(84.6 \%)$ \\
\hline & \multirow[t]{2}{*}{ 被 視 $(n=5)$} & $F$ & 3 & $(60.0 \%)$ \\
\hline & & $\mathrm{N}$ & 3 & $(60.0 \%)$ \\
\hline \multirow[t]{6}{*}{ 内紏䘽 $(n=15)$} & \multirow{2}{*}{ 量 $(n=5)$} & $F$ & 1 & $(20.0 \%)$ \\
\hline & & $\mathrm{N}$ & 0 & \\
\hline & \multirow[t]{2}{*}{ 眼精唛労 $(n=1)$} & $F$ & 0 & \\
\hline & & $\mathrm{N}$ & 0 & \\
\hline & \multirow[t]{2}{*}{ 被 䘽 $(n=9)$} & $F$ & 2 & $(22.2 \%)$ \\
\hline & & $\mathrm{N}$ & 8 & $(88.9 \%)$ \\
\hline
\end{tabular}

䍍胃立体視(F)は遠胃ポラテスト $2 / 4$ 以上を良好とした 近兒立体視 (N)はチトマスステレオテスト6/9以上を良好とした
存在する例が多いことが興味のあるところであ る。また複視が出現するか否かの検査では、眼 位をプリズムで矯正後に赤ガラス検查を行い、 何プリズム矯正で複視が出現するか、あるいは 全く出現しないかを検査した。さらに、バゴリ 二検査、残像検査で網膜対応を検査した。そし て患者希望の修正眼位と複視のでない程度の修 正眼位から手術量を決定した。手術方法は特に 従来のごとく、基礎型、開散過多型、輻輳不全 型外斜視、及び基礎型、開散不全型、輻輳過多 型内斜視に分け、それぞれに眼筋の選択、強化 弱化の比重を決定した。また、術前に斜視角の 大きな症例では計画的に手術を 2 回に分けた (計画的追加手術)。

斜視手術後は、1）眼位矯正が少なくとも第 一眼位において患者の期待と一致する。2）眼 精疲労が軽減または消失する。1）2）におい ては複視が出現しないことが条件である。3） 複視が主訴の患者は、複視が残存しても少なく とも第一眼位、さらに最も日常的に眼を用いる 範囲において気にならない。以上を評価し、主 訴に応じて 1 ） から 3 ）を満たせば結果良好と 判定した。

\section{IV. 結 果}

術後の平均判定時期は 12.3 ケであった。外 斜視では33名中、結果良好例は30名 $(90.1 \%)$ であった。このうち計画的追加手術を行った症 例は 3 名であり、初回手術後、1 名は 1 か月後、 2 名は 3 か月後に行った。結果不良例は 3 名 $(9.9 \%)$ であった。不良の 3 名は術後、眼位の もどりのため追加手術を必要とした。これら 3 名の術前眼位は65～80プリズムで、遠近とも両 眼視機能は不良であった。術後に複視を訴えた 症例は見られなかった。図 1 は外斜視手術前、 図 2 は術後 3 ケ月、図 3 は最終判定日の患者の 眼位である。術前の回帰直線の傾きは0.93で輻 輳不全型が多く、術後のもどりも少ないようで あった。

内斜視では15名中 14 名 $(93.3 \%)$ が結果良好 であった。不良例は 1 名で、強度近視があり、 近見時の眼位が過矯正（外斜視）となり複視を 


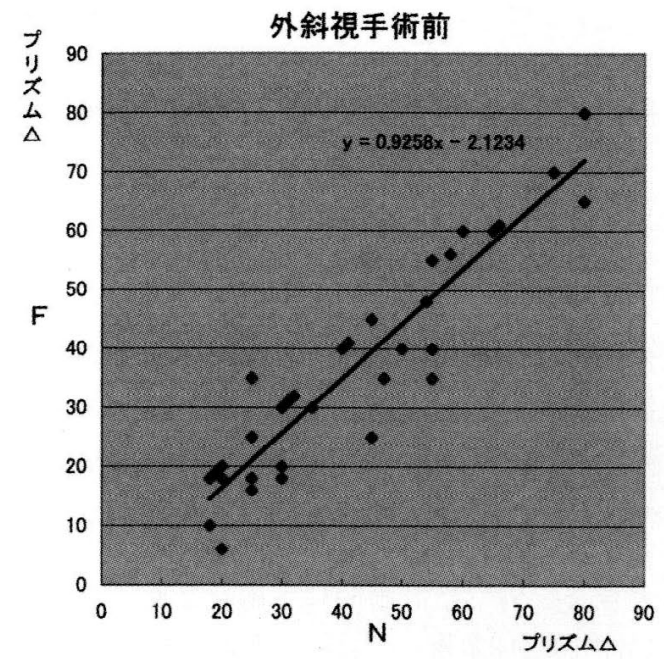

図 1 . 外斜視手術前の眼位

横軸は近見眼位、縦軸は遠見眼位。単位はプ リズム。

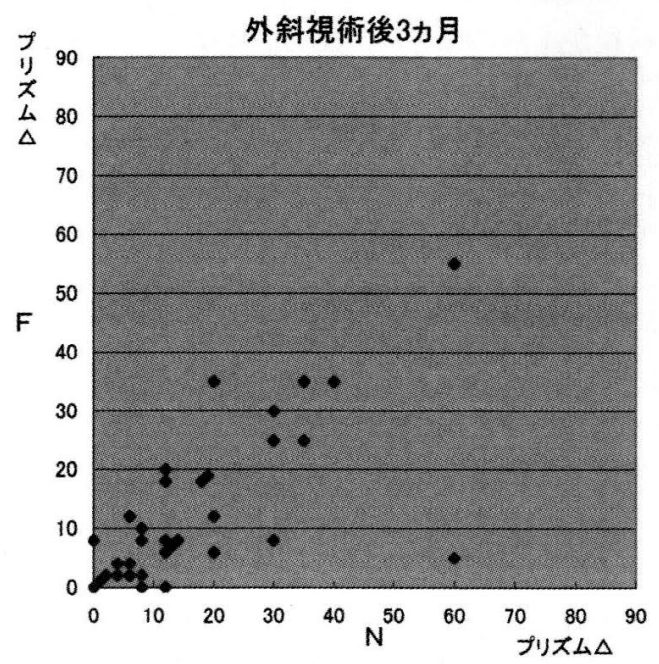

図 2. 外斜視手術後 3 ヶ月の眼位

訴えた。図 4 は内斜視手術前、図 5 は術後 3 ケ 月、図 6 は最終判定日の患者の眼位である。術

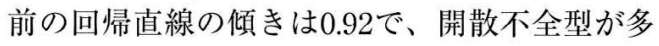
く見られた。術後のもどりは見られなかった。 また、主訴別の効果は表 3 のごとくである。

\section{V. 考案}

平成 7 年 6 月から平成 12 年 2 月の間に当院で

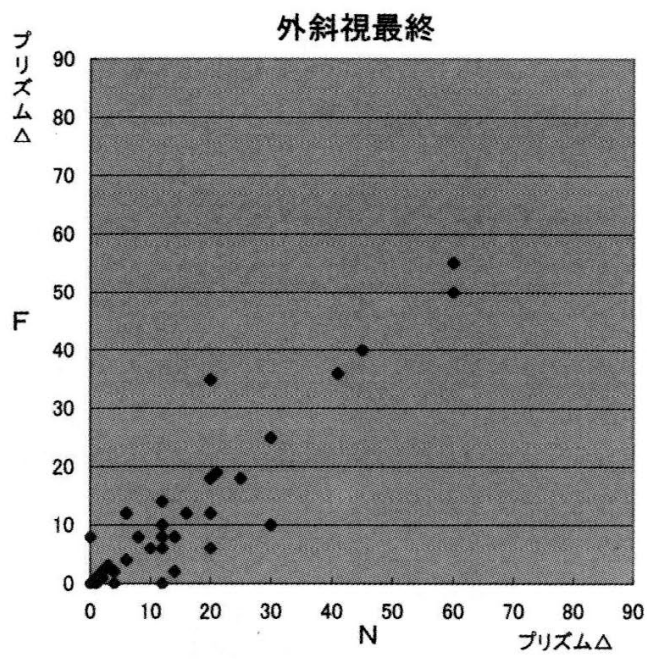

図 3 . 外斜視手術後最終判定日の眼位

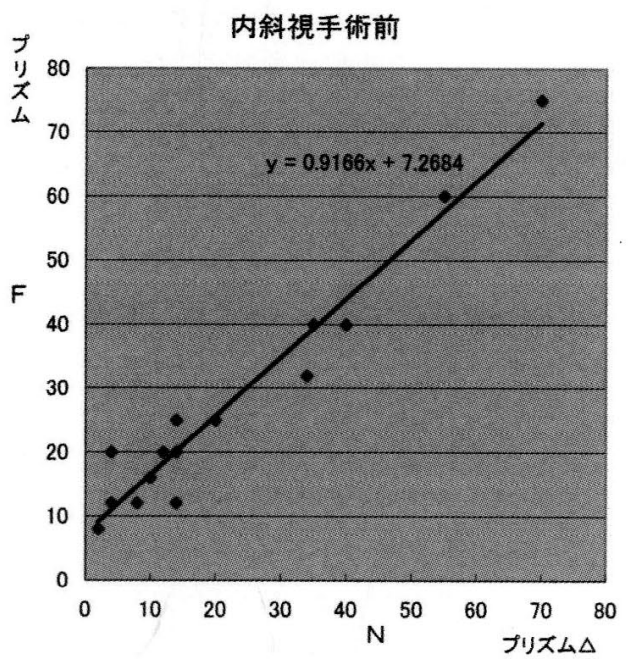

図 4. 内斜視手術前の眼位

横軸は近見眼位、縦軸は遠見眼位。単位はプ リズム。

斜視手術を施行した20歳以上の斜視は114名であ った。このうち、本調査期間中に当院で初回手 術を施行した水平斜視48名の手術成績について 検討した。

外斜視の術前の特徴は斜視角が大きく、また 輻輳不全型が多く見られた。小林ら ${ }^{1)}$ も高年齢 で受診するほど斜視角が大きくなると報告して おり、また木井ら ${ }^{2)}$ も40歳以上で遠近差は増大 し、輻輳不全型外斜視が多くなると報告してい 


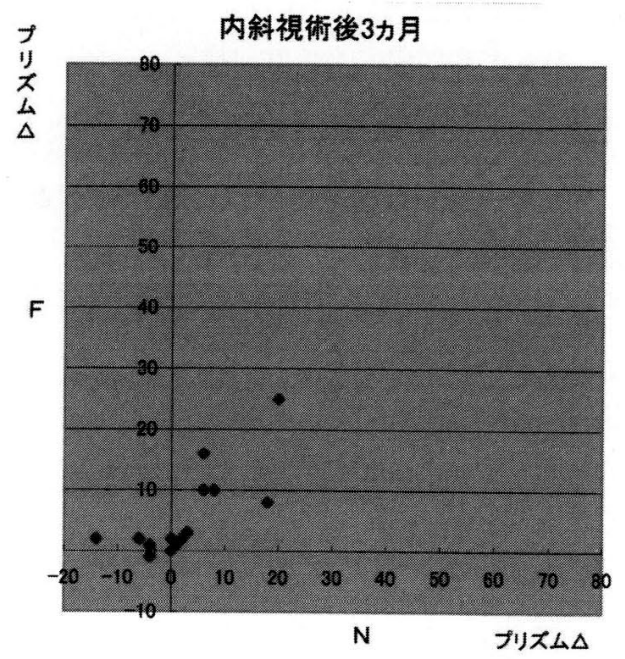

図 5.内斜視手術後 3 ヶ月の眼位

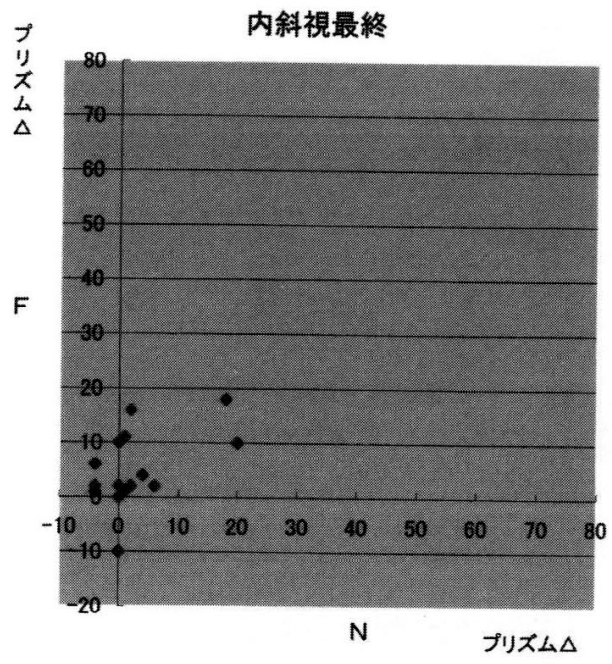

図 6. 内斜視手術後最終判定日の眼位

表 3 . 主訴別の効果

\begin{tabular}{|c|c|c|}
\hline & $\pm x$ & 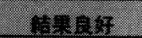 \\
\hline 外鈄視 $(n=33)$ & 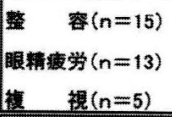 & $\begin{array}{cc}13 & (86.7 \%) \\
12 & (92.3 \%) \\
5 & (100.0 \%) \\
\end{array}$ \\
\hline 内斜視 $(n=15)$ & 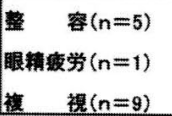 & $\begin{array}{ll}5 & (100.0 \%) \\
1 & (100.0 \%) \\
8 & (88.9 \%)\end{array}$ \\
\hline
\end{tabular}

る。原因として加齢による調節性輻輳の減弱が いわれており ${ }^{3)}{ }^{4)}$ 、そのため眼精疲労や複視が 現れ、主訴となったものと思われる。杰田ら ${ }^{5)}$ は外斜視術後のもどりは低年齢ほど早く大きい
と報告しているが、今回の成人の外斜視では術 後のもどりはあまり見られなかった。この結果 より、小児とは異なり術後のもどりを考慮に入 れた過矯正にする必要はないと思われた。結果 不良であった 3 名は術前斜視角が大きく、再眼 視機能も不良であった。しかし同様の術前状態 であっても術後の結果が良好な症例も多く、予 測はしがたいと思われる。少なくとも術前両眼 視機能が良好で、眼精疲労や複視を訴えた症例 の結果は良好であったため、このような症例で は予測ができる。久保四 $\left.{ }^{6}\right)$ が述べるように、特 に成人では術前の網膜対応検査の結果が重要で あり、今回も術後の複視の発生には特に注意を 払ったので、術後の複視は経験しなかった。

内斜視の術前の特徴は開散不全型が多く見ら れた。術後のもどりはほとんど見られなかった。 丸尾 ${ }^{7)}$ の報告でも、後天性内斜視では適矯正の 眼位を維持できるものが多いとしている。不良 であった 1 名は強度近視で視力は比較的良好で あるが、後極部網膜に近視性の網脈絡膜萎縮が 著明であった。術後しばらくは低矯正であった が、次第に外転が進行し、術後 1 年より近見が わずかに外斜視となり、複視を訴えるようにな った。原因は不明だが、強度近視の低矯正が影 響しているのかも知れない。

今回の我々の治療成績は、従来の眼位、而眼 視機能を主体とした斜視の治癒基準に照らし合 わせてという考えでなく、あくまで患者が手術 結果に満足したかどうかを問題にしていること で、これこそは医療の目的に合致していると考 えている。したがって表 3 のごとき満足度の成 績となった。

成人の斜視は敬遠されがちであるが、網膜対 応検査を含め、眼位矯正後、複視が出るか否か の検査を十分行っていれば、結果は良好で， quality of lifeに貢献すると思われた。

\section{参考文献}

1 ) 小林順子、岩重博康、久保田伸枝、他：間歇 性外斜視における斜視角の経年変化に関する 研究一間歇性外斜視患者の初診時年齢と斜視 角一。眼臨83：839-843、1989. 
2 ）木井利明、中井 喬 : 間歇性外斜視の自然経 過一各年代での術前斜視角の統計学的検討一. 日眼会誌96：904-909、1992.

3 ) Knapp P:Intermittent extropia: Evaluation and therapy. Am Orthop J $3: 27-33,1953$.

4 ) Von Noorden GK : Binocular vision and ocular motility (4th ed). St. Louis, The C.V Mosby Co., 323-339, 1990.

5 ）枱田亭二、横山 連、川波佳代、田中尚子：
外斜視手術の効果についてー手術年齢と術後 のもどりに関する統計的検討 - . 眼紀35： 690-696、 1984.

6 ）久保田伸枝: 成人の外斜視診察. 眼科診療プ ラクティス 60 : 92-102、文光堂、東京、 2000.

7 ）丸尾敏夫 : 斜視の手術に関する研究. 日眼会 誌 $91 ： 48-71 、 1987$. 